\title{
Post-embryonic Development of the Seminal Vesicle in the Stingless Bee Melipona quadrifasciata Lepeletier, 1836 (Apidae: Meliponini)
}

\author{
RP Ferreira, ha Werneck, J Malta, AD TeIXeira, LAO Campos, JE Serrão \\ Departamento de Biologia Geral, Universidade Federal de Viçosa, Viçosa-MG, Brazil
}

\author{
Article History \\ Edited by \\ Eduardo Almeida, USP, Brazil \\ Received 09 May 2018 \\ Initial acceptance 01 July 2018 \\ Final acceptance 14 December 2018 \\ Publication date 20 August 2019

\section{Keywords} \\ Hymenoptera, reproductive system, male \\ accessory glands.

\section{Corresponding author \\ Ríudo de Paiva Ferreira \\ Universidade Federal de Viçosa \\ Departamento de Biologia Geral \\ Avenida Ph Rolfs s/no, CEP: 36570000 \\ Viçosa, Minas Gerais, Brasil. \\ E-Mail: riudopaiva@gmail.com}

\begin{abstract}
The male accessory glands of stingless bees (Apidae: Meliponini) are absent and the morphology of their seminal vesicle indicate probable secretory function by this organ. This study investigated the post-embryonic development of the seminal vesicles in males of the stingless bee Melipona quadrifasciata by histology and histochemistry. White-eyed pupae, pink-eyed pupae, brown-eyed pupae, black-eyed pupae, newly emerged and sexually mature males were studied. Seminal vesicle has a wall with a single layered epithelium onto a thin basement membrane, followed by a well-developed muscle layer. The epithelium is polarized in the pupal stage with basal cell region strongly positive for glucoconjugates and carbohydrates. The seminal vesicle has an enlarged lumen from the young pupal stages with luminal content increasing gradually with glucoconjugates along the pupal development. In the newly emerged and mature males, the histochemical tests to carbohydrates were negative. In the sexually mature males, spermatozoa clusters are embedded by the glucoconjugates content of the seminal vesicle lumen. In conclusion, the seminal vesicle of $M$. quadrifasciata has a secretory function during the pupal stage and in newly emerged males, whereas in adult males this organ stores the spermatozoa.
\end{abstract}

\section{Introduction}

The male reproductive tract of insects has a pair of testes connected to an ejaculatory duct via two vasa deferentia (Snodgrass, 1935). In many insects, including those of the order Hymenoptera, there are regions termed seminal vesicles along the vasa deferentia, modified for spermatozoa storage. Accessory glands connect to the vasa deferentia or near the ejaculatory duct. The number of accessory glands may differ among species (Baer et al., 2000; Chapman, 2013).

The seminal vesicle is mesodermal in origin and consists of dilated portions of vasa deferentia (Chapman, 2013). In eusocial honeybees, the seminal vesicle is an elongated tube (Cruz-Landim \& Cruz-Höfling, 1969; Sawarkar \& Tembhare, 2014), whereas in stingless bees (Meliponini), it is spherical (Dallacqua \& Cruz-Landim, 2003; Cruz-Landim,
2009). In Meliponini, newly emerged males have empty seminal vesicles with epithelial cells characterized by apical microvilli and collapsed lumen, whereas in sexually mature males, the seminal vesicle is filled with spermatozoa with a cubic epithelium (Lima et al., 2006).

The male accessory glands in bees are structures of mesodermic origin and open into the ejaculatory duct, releasing compounds that are transferred into the female together with spermatozoa during mating (Chen, 1984; Gillot, 1988, 2003). The accessory glands are already formed in newly emerged adult insects and their activity increases during the first days of emergence in the adult insect (Chapman 2013, Xu et al., 2015). In bees, accessory gland secretions are proteins, but can also include carbohydrates and lipids (Blum et al., 1962; Blum et al., 1967; Chen, 1984; Baer et al., 2000; Boomsma et al., 2005; Colonello \& Hartfelder, 2005; Gorshkov et al., 2015). 
This secretion affects female reproductive biology after mating, including protection, storage and activation of sperm, sperm competition, responsiveness inhibition, and fecundity enhancement (Fausto et al., 2000; Baer \& Boomsma, 2004).

Stingless bees are particularly interesting, because male accessory glands are absent (Ferreira et al., 2004), suggesting that the epithelial cells of seminal vesicles, vasa deferentia or the ejaculatory duct play a role in the secretion of compounds to form sperm (Dallacqua \& Cruz-Landim, 2003; Araújo et al., 2005). It has been shown (Dallacqua \& Cruz-Landim, 2003; Brito et al., 2010) that the epithelial cells of the seminal vesicle Melipona bicolor Lepeletier, 1938 have secretory activity.

This study describes the post embryonic development of the seminal vesicle in Melipona quadrifasciata Lepeletier, 1836, providing further evidence that seminal vesicles, in substitution for male accessory glands, produce compounds in stingless bees.

\section{Materials and Methods}

Male pupae and adults of $M$. quadrifasciata were obtained from three colonies kept at Apiário Central ("Central Apiary"), Universidade Federal de Viçosa (Viçosa, MG, Brazil). Brood combs were transferred to laboratory at $28{ }^{\circ} \mathrm{C}$ and five individuals of each white-eyed pupae (WEP), pink-eyed pupae (PEP), brown-eyed pupae (BwP) and black-eyed pupae (BIP), were collected from brood cells with forceps. The newly emerged males $(\mathrm{n}=5)$ were collected immediately after emerging from the brood cells. Sexually mature males $(n=5)$ were collected 15 days after emerging from the brood cells. Vouchers specimens were deposited in the entomological collection of Apiário Central-Universidade Federal de Viçosa (UFV).

Males were dissected in presence of $0.1 \mathrm{M}$ sodium phospate buffer $\mathrm{pH} 7.6$ (PBS) and the reproductive tracts transferred to Zamboni's fixative solution (Stefanini et al., 1967) for $4 \mathrm{~h}$. After washing in PBS, samples were dehydrated in a graded ethanol series $\left(70,80,90,95^{\circ}\right)$ and embedded in JB-4 historesin. Tissue seccions of $2 \mu \mathrm{m}$ thin were obtained from the Leica RM2255 Rotary Microtome and were stained with hematoxylin and eosin.

To characterize the biochemical composition of the luminal contents of the vesicles, some tissue sections were submitted to the following histochemical tests: PAS for glycogen and neutral carbohydrates (Junqueira \& Junqueira, 1983); Alcian blue $\mathrm{pH} 2.5$ for glucoproteins; Nile blue for lipids and Mercury bromophenol blue for total proteins (Bancroft \& Gamble, 2008). All sections were examined in Zeiss Primo Star light microscopy.

\section{Results}

The seminal vesicle of $M$. quadrifasciata is a paired spherical structure found in all pupal stages. It has an enlarged lumen lined by a single layer of columnar cells in all pupal stages and in newly emerged males (Fig 1a-g). In the adult males the epithelium becomes cubic (Fig 2). All stages are presents onto a thin basal membrane followed by thin muscle layer (Figs 1,2).
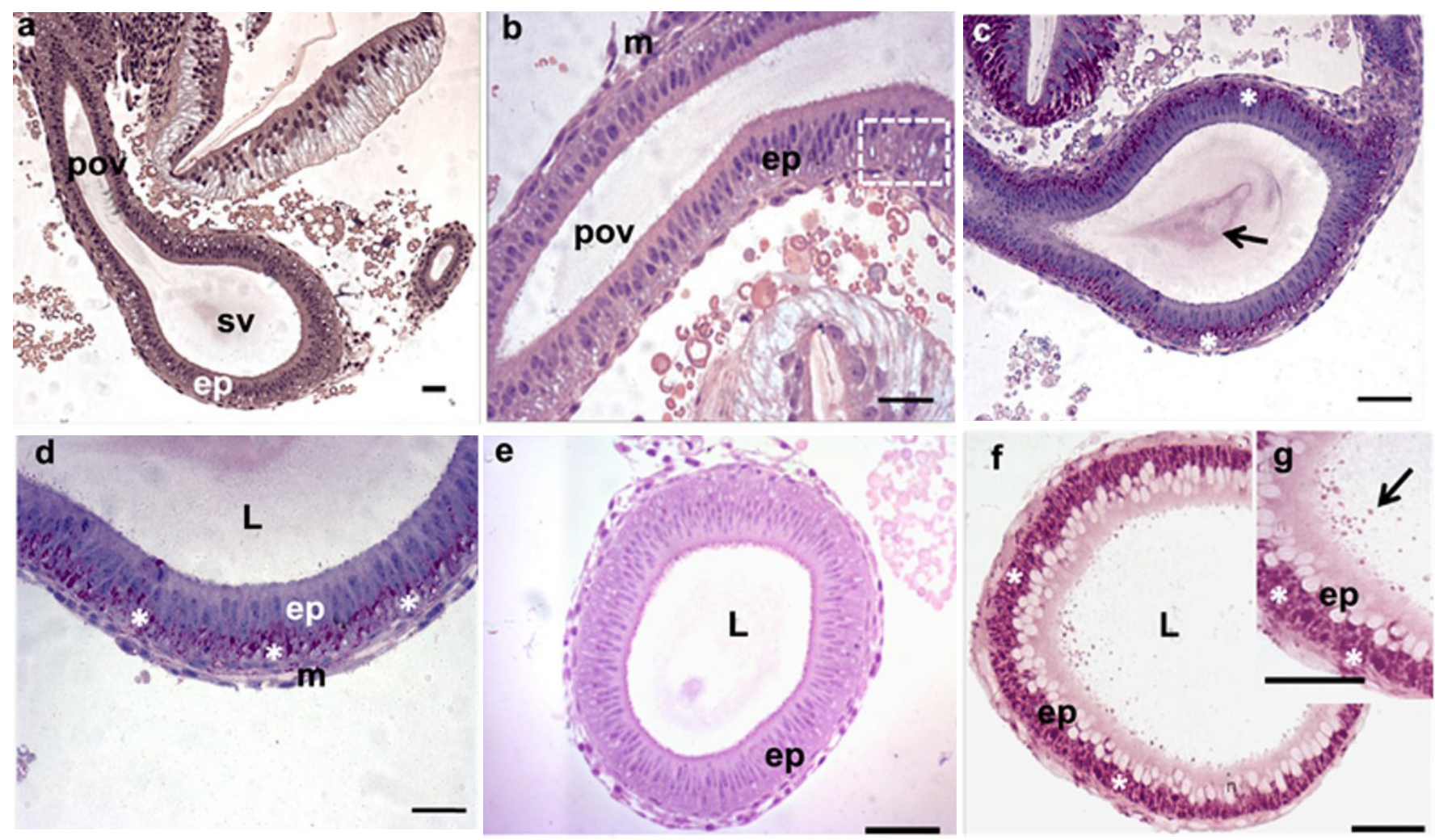

Fig 1. Histology of the seminal vesicles of pupae and adult males of Melipona quadrifasciata. (a-d) White-eyed pupae (WEP). (a) WEP with wide lumen. (b) clear areas in the basal cell region (dashed rectangle). (c-d) positive PAS reaction in the basal region of the epithelium (asterisks) and lumen (arrow) of the vesicle of the WEP. (e-g) Pink-eyed pupae as seen for the WEP seminal vesicles. Abbreviations: (ep) seminal vesicle epithelium, (L) seminal vesicle lumen, (n) nuclei, (m) muscular sheath, (pov) post vesicular deferent duct. Scale bar $=20 \mu \mathrm{m}$. 
Hematoxylin-eosin staining (Fig 1a) revealed that the epithelial cells of seminal vesicles have nuclei in the median cell portion, whereas the basal cell portion presents clear areas (Fig 1b), which shows a positive PAS reaction (Fig 1c,d). The clear areas in the basal cell portion increased in size with advancement of pupal development (Fig 1d, 2a). However, in both newly emerged and sexually mature adult males, the epithelial cells of the seminal vesicles were uniformly stained (Fig 2d,h), although in mature males the cells were cubical (Fig 2h). In newly emerged males, the seminal vesicles showed an amorphous luminal content (Fig 2d-g).
The clear basal cell region of the seminal vesicle epithelium was strongly positive for PAS test showing the presence of neutral carbohydrates in all pupal stages (Figs $1 \mathrm{c}, \mathrm{d}, \mathrm{f}, \mathrm{g}, 2 \mathrm{~b}, \mathrm{c}, \mathrm{g})$. The luminal content of the seminal vesicle was PAS-positive in white-eyed pupae (Fig 1c, d). In pink-eyed pupae, the apical surface of the seminal vesicle epithelium had PAS-positive granules (Fig 1e-g). In brown-eyed pupae, carbohydrates were stored throughout the cell cytoplasm of the seminal vesicle (Fig 2b-c,g). In the black-eyed pupae, the amount of carbohydrates stored was higher in the basal cell region (Fig 2 c) and lumen. Small lipid droplets (Fig 2 e) were
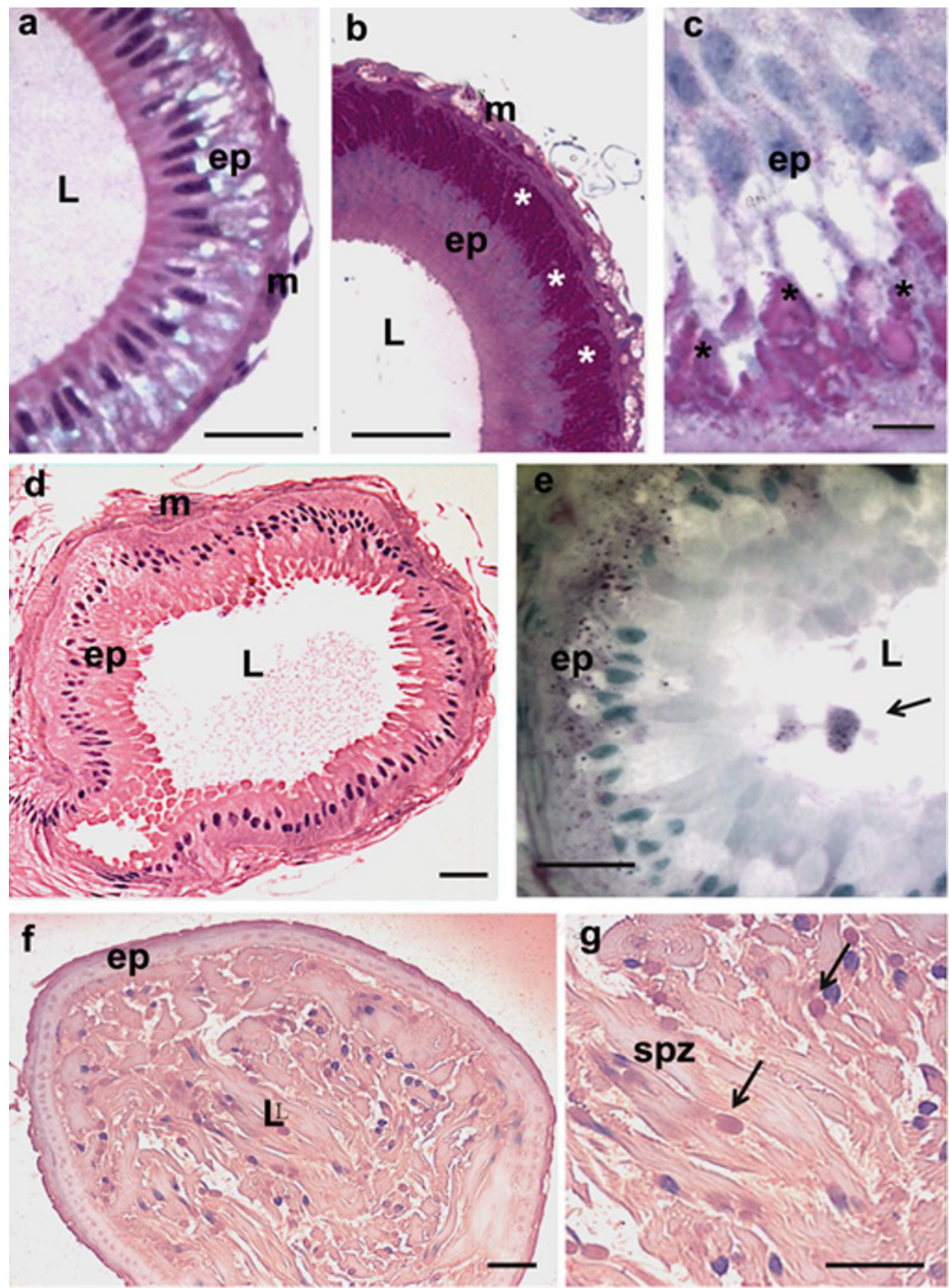

Fig 2. Histology of the seminal vesicles of pupae and adult males of Melipona quadrifasciata. (a) detail of the columnar epithelium of the Browneyed pupae (BwP). (b) seminal vesicle of the BwP. (c) Black-eyed pupae (BIP). The asterisks indicate the carbohydrates in cytoplasm of the cells in the basal region of the epithelium. (d) vesicle of the newly emerged male with secretion in the lumen. (e) lipid droplets (arrow) of uniform size in the apical portion of the epithelium. (f-g) Sexually mature male. (f) seminal vesicle showing the luminal region (L) filled with sperm and, the cubic epithelium (ep). (g) The PAS-positive granules involve the spermatozoa bundles (arrow) in seminal vesicle luminal region. Scale bar $=20 \mu \mathrm{m}$. 
found in the apical cell region of the seminal vesicle epithelium of brown and black-eyed pupae. Protein content was found in all cells of the seminal vesicle, but not stored in secretory granules.

In newly emerged males, the cells of the seminal vesicle were PAS-positive (Fig 2d, e), whereas in sexually mature ones, when the seminal vesicle was filled with spermatozoa, the epithelial cells did not possess neutral carbohydrate storage (Fig 2f), despite the presence of PAS-positive granules in the lumen of the seminal vesicle (Fig $2 \mathrm{~g}$ ). These granules were found to be associated with the luminal content of the vesicle along with the spermatozoa bundles (Fig 2g). The main changes in the epithelium of seminal vesicles of $M$. quadrifasciata during the pupal development and after adult emergence are summarized in the Table 1.

\section{Discussion}

The histology of the seminal vesicle was similar along the entire pupal stage of $M$. quadrifasciata. It suggests that the differentiation of this region of the male reproductive tract occurs in early white-eyed pupae. In fact, spermatogenesis in stingless bees begins during the pupal stage (CruzLandim \& Dallacqua, 2002) and the spermatozoa storage organ should be functional during this developmental stage. The seminal vesicle of $M$. quadrifasciata pupae is enlarged and filled with amorphous content, like that in Melipona mondury Smith, 1863 (Lima et al., 2006), contrasting with narrow and empty lumen of seminal vesicles of newly emerged males of Scaptotrigona xanthotricha Moure, 1950
(Araujo et al., 2005) and Friesella schrottkyi (Friese, 1900) (Brito et al., 2010).

Our histochemical tests show the presence of glucoconjugates in the epithelial cells of the seminal vesicles of pupae and newly emerged males, but its absence in mature ones. In the latter, glucoconjugates occur associated with spermatozoa bundles in the seminal vesicle lumen, suggesting that these compounds are produced during the pupae stage and released to the seminal vesicle. In mature males of other Meliponini species, it has been reported that glycoprotein coating spermatozoa bundles into the seminal vesicle (Moreira et al., 2004; Cruz-Landim, 2009).

The presence of lipid droplets in the apical region of the seminal vesicle epithelium in late black-eyed pupae suggests that this compound may be used for spermatozoa maintenance during storage in adult. Fatty acids are found in male accessory glands in bumblebees (Baer et al., 2000). Because secretions of male accessory glands are released during insect mating and transferred together with spermatozoa to the female (Colonello \& Hartfelder, 2005; den Boer et al., 2009, 2015), compounds similar to those produced in these glands may be synthesized in the seminal vesicle of stingless bees. Tozetto et al. (2007) pointed out an increase in the protein content in the seminal vesicle of late pupae of Apis mellifera Linnaeus, 1758, which may be due to organ growth. Furthermore, Sawarkar \& Tembhare (2014) showed that the seminal vesicle in Apis cerana indica Fabricius, 1798 has secretory activity with high protein content, followed by lipids and carbohydrates, which may aid in the storage and survival of spermatozoa in the seminal vesicle.

Table 1. Main characteristics of the seminal vesicle during post-embryonic development of males of Melipona quadrifasciata, by Histochemical tests. Test positive (+) and negative (-).

\begin{tabular}{|c|c|c|c|c|}
\hline \multirow[b]{2}{*}{ Stage of development } & \multicolumn{3}{|c|}{ Histochemical tests } & \multirow[b]{2}{*}{ Characteristics of seminal vesicle } \\
\hline & PAS & Nile blue & $\begin{array}{c}\text { Mercuric } \\
\text { bromophenol blue }\end{array}$ & \\
\hline White-eyed pupae & + & - & + & $\begin{array}{l}\text { Lumen enlarged, filled with amorphous content, epithelium high, nucleus } \\
\text { in the middle portion of the cell, basal region with weakly stained clear } \\
\text { areas. Carbohydrate storage in the basal region of the epithelium. }\end{array}$ \\
\hline Pink-eyed pupae & + & - & + & $\begin{array}{l}\text { Lumen enlarged, filled with amorphous content, epithelium high, nucleus } \\
\text { in the middle portion of the cell, basal region with weakly stained clear } \\
\text { areas. Basal region of the epithelium with PAS-positive granules. }\end{array}$ \\
\hline Brown-eyed pupae & + & + & + & $\begin{array}{l}\text { Lumen enlarged, filled with amorphous content, epithelium high, nucleus } \\
\text { in the middle portion of the cell, Large clear areas in the basal region of the } \\
\text { epithelium. High carbohydrate storage in the basal portion, PAS-positive } \\
\text { granules dispersed in the cell cytoplasm. Lipid droplets of uniform size in } \\
\text { the apical portion of the epithelium. }\end{array}$ \\
\hline Black-eyed pupae & + & + & + & $\begin{array}{l}\text { Lumen enlarged, filled with amorphous content, epithelium high, nucleus } \\
\text { in the middle portion of the cell, basal region with weakly stained clear } \\
\text { areas. Basal portion of the epithelium strongly PAS-positive. Lipid } \\
\text { droplets present. Luminal content with carbohydrate. }\end{array}$ \\
\hline Newly emerged male & + & - & + & $\begin{array}{l}\text { Lumen enlarged, Epithelium high and uniformly stained. Low carbohydrate } \\
\text { storage in the basal portion of the epithelium. Luminal content with } \\
\text { carbohydrate. }\end{array}$ \\
\hline Sexually mature male & - & - & + & $\begin{array}{l}\text { Lumen enlarged, Epithelium cubic uniformly stained, without lipids } \\
\text { and carbohydrates storage. Luminal content with PAS-positive granules } \\
\text { associated with spermatozoa bundles. }\end{array}$ \\
\hline
\end{tabular}


The histochemical composition of the luminal contents of the seminal vesicle of $M$. quadrifasciata during the pupal stages shows a large amount of carbohydrates, low lipid and protein contents, which may act in reducing oxidative stress during the storage of spermatozoa in the organ. Although experimental manipulations suggest multiple mating in $M$. quadrifasciata (Lopes et al., 2003) and microsatellite analyses confirm polyandry in M. mondury (Viana et al., 2015), the ejaculated material during sperm transfer associated with the physical barrier of the chitin-lined organs of the reproductive tract in M. quadrifasciata may favor the monarchical behavior of this bee, preventing multiple mating.

The epithelium of the seminal vesicle of $M$. quadrifasciata is polarized during the pupal stage with the basal cell region storing neutral carbohydrates and glucoconjugates. In addition, the seminal vesicle lumen is enlarged in early white-eyed pupae being gradually filled by PAS-positive content, whereas in adult males, storage of organic compounds in the lumen is reduced. These findings, together with similar results among other Meliponini (Dallacqua \& Cruz-Landim, 2003; Araújop., 2005; Lima et al., 2006), suggest that the seminal vesicle plays a dual role in stingless bees: in pupae and newly emerged males, it is a secretory organ, whereas in sexually mature males, the seminal vesicle functions as a spermatozoa storage organ, overlaying the absence of male accessory glands in Meliponini.

\section{Acknowledgments}

This research was supported by the Brazilian research agencies FAPEMIG, CNPq and CAPES. The authors are also grateful to the two anonymous reviewers for their suggestions for improving the quality of the manuscript.

\section{References}

Araújo V.A., Zama U., Neves C.A., Dolder H. \& LinoNeto J. (2005). Ultrastructural, histological and histochemical characteristics of the epithelial wall of the seminal vesicle of mature Scaptotrigona xanthotricha Moure males (Hymenoptera, Apidae, Meliponini). Brazilian Journal of Morphological Sciences, 22: 193-201.

Baer, B. \& Boomsma, J.J. (2004). Male reproductive investment and queen mating frequency in fungus growing ants. Behavioral Ecology, 15: 426-432. doi: 10.1093/beheco/arh025

Baer, B., Maile, R., Schmid-Hempel, P., Morgan, E.D. \& Jones, G.R. (2000). Chemistry of a mating plug in bumblebees. Journal of Chemical Ecology, 26: 1869-1875. doi: 10.1023/A: 100559670

Bancroft, J.D. \& Gamble, M. (2008). Theory and pretice of histological techniques. London: Churchill Livingstone, , 725 p.

Blum, M.S., Bumgarner, J.E. \& Tauber III, S. (1967). Composition and possible significance of fatty acids in lipids classes of honeybee serum. Journal of Insect Physiology, 13: 1301-1308.

Blum, M.S., Glowska, Z. \& Tauber III S. (1962). Chemistry of the drone honeybee reproductive system. II. Carbohydrates in the reproductive organs and semen. Annals of the Entomological Society of America, 55: 135-139.

Boomsma, J.J., Baer, B. \& Heinze, J. (2005). The evolution of male traits in social insects. Annual Review of Entomology, 50: 395-420. doi: 10.1146/annurev.ento.50.071803.130416

Brito, P., Zama U., Dolder H. \& Lino-Neto J. (2010). New characteristics of the male reproductive system in the Meliponini bee, Friesella schrottkyi (Hymenoptera: Apidae): histological and physiological development during sexual maturation. Apidologie, 41: 203-215. doi: 10.1051/apido/2009071

Chapman, R.F. (2013). The Insects: Structure and Function. Cambridge University Press, 959 p.

Chen, P.S. (1984). The functional morphology and biochemistry of insect male accessory glands and their secretions. Annual Review of Entomology, 29: 233-255.

Colonello N.A. \& Hartfelder, K. (2005). She's my girl male accessory gland products and their function in the reproductive biology of social bees. Apidologie, 36: 231-244. doi: 10.1051/apido:2005012

Cruz-Landim, C. \& Cruz-Höfling, M. A. (1969). Electron microscope observations on honeybee seminal vesicles (Apis mellifera adansonii, Hymenoptera, Apidae). Papéis Avulsos de Zoologia, 22: 145-151.

Cruz-Landim C. \& Dallacqua, R.P. (2002). Testicular reabsorption in adult males of Melipona bicolor Lepeletier (Hymenoptera, Apidae, Meliponini). Cytologia, 67: 145-151. doi: 10.1508/ cytologia.67.145

Cruz-Landim, C., 2009. Abelhas: Morfologia e Função. São Paulo: Editora Unesp. 407 p.

Dallacqua R.P. \& Cruz-Landim, C. (2003). Ultrastructure of the ducts of the reproductive tract of males of Melipona bicolor bicolor Lepeletier (Hymenoptera, Apinae, Meliponini), Anatomia Histologia Embryologia, 32: 276-281. doi: 10.1046/j.1439-0264.2003.00484

den Boer S.P.A., Boomsma, J. \& Baer, B. (2009). Honeybee males and queens use glandular secretions to enhance sperm viability before and after storage. Journal of Insect Physiology, 55: 538-543. doi:10.1016/j.jinsphys.2009.01.012

den Boer S.P.A., Sturup, M., Boomsma, J. \& Baer, B. (2015). The ejaculatory biology of leafcutter ants. Journal of Insect Physiology, 74: 56-62. doi: 10.1016/j.jinsphys.2015.02.006

Fausto, A.M, Gambellini, A.R., Taddei, A.R., Maroli, M. \& Mazzini, M. (2000). Ultrastructure of the vesicle of Phlebotomus perniciosus Newstead (Diptera, Psychodidae). Tissue and Cell, 32: 228-237. doi: 10.1054/tice.2000.0110 
Ferreira A., Abdalla, F.C., Kerr W.E. \& Cruz-Landim C. (2004). Comparative anatomy of the male reproductive internal organs of 51 species of bees. Neotropical Entomology, 33: 569-576. doi: 10.1590/S1519-566X2004000500005

Gillot, C. (2003). Male accessory gland secretions: modulators of female reproductive physiology and behavior. Annual Review of Entomology, 48: 163-184. doi: 10.1146/annurev. ento.48.091801.112657

Gillot, C. (1988). Arthropoda-Insecta. In: Adiyodi, K.G. \& Adiyodi, R.G. (Eds), Reproductive Biology of Invertebrates (pp. 319-371). New York: Wiley press.

Gorshkov, V., Blenau, W., Koeniger, G., Römpp, A., Vilcinskas, A. \& Spengler, B. (2015). Protein and Peptide Composition of Male Accessory Glands of Apis mellifera Drones Investigated by Mass Spectrometry. PLoS ONE, 10: e0125068. doi: 10.13 71/journal.pone.0125068.

Junqueira, L.C.U. \& Junqueira, M.M.S. (1983). Técnicas básicas de citologia e histologia. São Paulo: Editora Santos, 123 p.

Lima, M.A.P., Lino-Neto, J. \& Campos, L.A.O. (2006). Sexual maturation in Melipona mondury males (Apidae: Meliponini). Brazilian Journal of Morphological Sciences, 23: 369-375.

Lopes, D.M., Tavares, M.G. \& Campos, L.A.O. (2003). Sperm utilization by Melipona quadrifasciata Lepeletier (Hym., Apidae) queens subjected to multiple mating. Insectes Sociaux, 50: 387-389. doi: 10.1007/s00040-003-0694-0

Moreira J., Zama U. \& Lino-Neto J. (2004). Release, behavior and phylogenetic significance of spermatozoa in bundles in the seminal vesicle during sexual maturation in Aculeata (Hymenoptera). Brazilian Journal of Morphological Sciences, 21: 185-189.

Stefanini, M.C. \& De Martino, Zamboni, L. (1967). Fixation of ejaculated spermatozoa for electron microscopy. Nature, 216: 173-174. doi: 10.1038/216173a0

Snodgrass, R.E. (1935). Principles of insect morphology. New York and London: McGraw-Hill Book Company, Inc, 667 p.

Sawarkar, A.B. \& Tembhare, D.B. (2014). Development and secretory nature of seminal vesicle during sexual maturation in Indian honeybee, Apis cerana indica F. (Hymenoptera: Apidae). Journal of Entomology and Zoology Studies, 2: 105-109.

Tozetto, S. O., Bitondi, M. M. G., Dallacqua, R. P. \& Simões, Z.L.P. (2007). Protein profiles of testes, seminal vesicles and accessory glands of honeybee pupae and their relation to the ecdysteroid titer. Apidologie, 38: 1-11. doi: 10.1051/ apido:2006045

Viana, M.V.C., de Carvalho, C.A.L., Sousa, H.A.C., Francisco, A.K. \& Waldschmidt, A.M. (2015). Mating frequency and maternity of males in Melipona mondury (Hymenoptera: Apidae). Insectes Sociaux, 62: 491-495. doi: 10.1007/s00040-015-0428-0

Xu, J., Anciro, A.L. \& Palli, S.R. (2015). Nutrition regulation of male accessory gland growth and maturation in Tribolium castaneum. Scientific reports, v. 5, p. 10567. doi: 10.1038/ srep 10567.

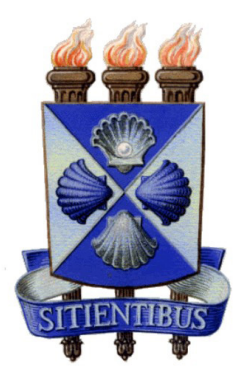

